Pomáhajúce profesie, roč. 4, č. 2, 2021, 55-62

\title{
PSYCHOMETRICKÉ VLASTNOSTI SLOVENSKEJ VERZIE DOTAZNÍKA UTRECHT PROACTIVE COMPETENCE COPING SCALE
}

\author{
Miriama Hudáková1, Katarína Baňasová1, Boris Katrušín ${ }^{2}$ \\ 1Ústav aplikovanej psychológie FSVaZ UKF Nitra1 \\ ${ }^{2}$ Katedra psychologických vied FSVaZ UKF Nitra² \\ kbanasova@ukf.sk,mhudakova2@ukf.sk
}

\begin{abstract}
Abstrakt: Ciel'om predkladanej štúdie je analýza reliability a faktorovej štruktúry slovenského prekladu nástroja Utrecht Proactive Competence Coping Scale (Bode, Thoolen, de Ridder, 2008), ktorý je určený pre pacientov v rekonvalescencii po cievnej mozgovej príhode. Výskumný súbor pozostával zo 77 pacientov - 50 (64,9\%) mužov a 27 žien $(35,1 \%)$, ktorí prekonali CMP. Na overenie faktorovej štruktúry dotazníka sme použili metódu exploračnej faktorovej analýzy, kde okrem štruktúry originálneho jednofaktorového modelu navrhujeme aj štvorfaktorový model. Výsledky poukazujú na vhodnejšiu štvorfaktorovú štruktúru dotazníka UPCC, dobré hodnoty vnútornej konzistencie dotazníka v jeho jednofaktorovej aj štvorfaktorovej štruktúre. Limitom štúdie je menší počet respondentov. Za prínos analýz považujeme identifikáciu štyroch možných faktorov dotazníka, ktoré podnecujú detailnejší náhl’ad na proaktívne zvládacie mechanizmy pacientov po CMP.
\end{abstract}

Klučové slová: proaktívne zvládanie, cievna mozgová príhoda, psychometrické vlastnosti

\section{1 ÚVOD}

Cievna mozgová príhoda (CMP) je tret’ou najčastejšou príčinou smrti v rozvinutých krajinách (Mackay, Mensah, 2004). V nasledujúcich rokoch sa očakáva výrazné zvýšenie počtu l'udí, ktorí prekonali cievnu mozgovú príhodu v dôsledku klesajúcej úmrtnosti populácie a jej starnutia (Sarti et al., 2003; United Nations, 2009). Cievna mozgová príhoda je negatívna životná udalost', na ktorú môžu pacienti reagovat' depresiou, a to v závislosti od interakcie medzi osobnost'ou a závažnost'ou negatívnych fyzických, psychologických a sociálnych dôsledkov po cievnej mozgovej príhode (Aben et al., 2001). Pacienti, ktorí prežijú cievnu mozgovú príhodu často zažívajú výrazný pokles v ich kvalite života súvisiacej so zdravím (Haley et al., 2011; Darlington et al., 2009; Kauhanen et al., 2000). Mnoho pacientov musí prispôsobit' svoj život pretrvávajúcim následkom CMP. Dôležitým determinantom tohto procesu, ako aj samotnej kvality života sú stratégie zvládania zátaže (Tielemans, et al., 2014; Carod-Artal, Egido, 2009; Darlington et al., 2009). V predkladanej štúdii preto venujeme pozornost' proaktívnemu zvládaniu zát'aže u pacientov po cievnej mozgovej príhode, pričom hlavným ciel’om štúdie je overenie psychometrických vlastností slovenskej verzie dotazníka Utrecht Proactive Competence Coping Scale (Bode, Thoolen, de Ridder, 2008), ktorý je určený k meraniu proaktívnych zvládacích kompetencií.

\subsection{Proaktívne zvládanie u pacientov po cievnej mozgovej príhode}

Klasickú definíciu zvládania zát’aže podávajú Lazarus a Folkmanová (1984), ktorí zvládanie chápu ako komplex kognitívnych a behaviorálnych snáh jednotlivca so zámerom zvládnut', redukovat' alebo tolerovat' interné alebo externé požiadavky, ktoré ohrozujú alebo presahujú zdroje indivídua. $\mathrm{V}$ minulosti sa zvládanie zát’aže považovalo za reaktívnu stratégiu, ktorú človek použije 
ked' sa stres už vyskytol. V súčasnosti sa zvládanie zát'aže čoraz viac chápe ako spôsob zmierňovania stresu a podpory kvality života (Greenglass, 2002). Zvládanie zát'aže sa tu chápe ako niečo, čo môže jednotlivec urobit' ešte predtým, než sa stres vyskytne a má tak pre jednotlivca viacnásobný pozitívny význam (Greenglass, Fiksenbaum, 2009). Takýto pohl'ad na zvládanie predstavuje koncept proaktívneho zvládania zát'aže. Považujeme za dôležité zaoberat' sa práve proaktívnym zvládaním zát’aže u pacientov po CMP, nakol'ko podl'a Tielemansa et al. (2014) sa aj v tejto súvislosti venuje menej pozornosti proaktívnym stratégiám zvládania zát’aže v porovnaní s klasickou reaktívnou perspektívou. Podl'a autora proaktívne zvládacie stratégie predstavujú snahu l'udí predvídat' výskyt potenciálnych negatívnych dôsledkov CMP skôr než začnú čelit' týmto dôsledkom čo najefektívnejším spôsobom. Mnoho pacientov totiž musí prispôsobit' svoj život pretrvávajúcim následkom CMP, pričom významným determinantom tohto procesu sú stratégie zvládania zát'aže (Tielemans, et al., 2014; Carod-Artal, Egido, 2009; Darlington et al., 2009), v našom prípade proaktívne zvládacie kompetencie. Očakáva sa, že proaktívne zvládanie povedie k lepšiemu prispôsobeniu sa chronickým stavom, akým je aj stav po CMP, pretože umožňuje pacientom predchádzat' a vopred sa pripravit' na jeho reštriktívne dôsledky (Tielemans et al., 2014). Vzhl'adom k uvedenému sa zhodujeme s názorom Tielemansa et al. (2014), podl’a ktorých by intervencie pre pacientov po cievnej mozgovej príhode mali byt' zamerané na osvojenie si proaktívnych zvládacích stratégií, čo si však vyžaduje psychometricky kvalitný nástroj na posúdenie úrovne proaktívneho zvládania u pacientov za účelom zistit' účinnost' takýchto intervencií. Preto je ciel’om našej štúdie v slovenských podmienkach overit' psychometrické vlastnosti slovenskej verzie dotazníka Utrecht Proactive competence coping scale (Bode, Thoolen, de Ridder, 2008), ktorý v zahraničí preukazuje potenciál na spol'ahlivé a valídne meranie proaktívnych zvládacích kompetencií u pacientov po cievnej mozgovej príhode.

\subsection{Overenie psychometrických vlastností slovenskej verzie dotazníka Utrecht Proactive competence coping scale - vnútorná konzistencia a faktorová štruktúra}

Ciel’om predkladanej štúdie je overenie psychometrických vlastností slovenskej verzie dotazníka Utrecht Proactive competence coping scale, a to konkrétne jeho vnútornej konzistencie a faktorovej štruktúry. Vnútornú konzistenciu budeme zist'ovat’ Cronbachovým koeficientom alfa. Overíme jednofaktorovú štruktúru navrhovanú autormi dotazníka, ktorá meria jeden faktor zist'ujúci mieru proaktívnych zvládacích kompetencií pacientov po CMP. Vzhl'adom na výsledky budeme d'alej explorovat' a postupovat' pri analýze aj iných faktorových riešení, ak sa pôvodný navrhovaný faktorový model nebude javit’ ako ideálny.

\section{METÓDY}

\subsection{Výskumná vzorka}

Výskumný súbor pozostával z 77 pacientov - 50 (64,9\%) mužov a 27 žien (35,1\%), ktorí prekonali cievnu mozgovú príhodu s $\mathrm{M}_{\mathrm{vek}}=68,17 ; \mathrm{SD}=12,4$. S ischemickou cievnou mozgovou príhodou bolo $67(87 \%)$ pacientov, s hemoragickou príhodou $6(7,8 \%)$ pacientov a $4(5,2 \%)$ pacienti neuviedli typ CMP.

\subsection{Meracie nástroje}

Utrecht Proactive Coping Competence Scale -UPCC (Bode, Thoolen, de Ridder, 2008)

V štúdii overujeme psychometrické vlastnosti slovenskej verzie dotazníka Utrecht Proactive Coping Competence Scale (Bode, Thoolen, de Ridder, 2008).

UPCC prostredníctvom sebahodnotenia meria proaktívne zvládacie kompetencie. 21 položiek dotazníka je hodnotených na 4-bodovej škále od „nie som toho vôbec schopný“ po „vel'mi schopný“. Príklady položiek sú nasledovné: „Do akej miery máte schopnost’ robit’ realistické plány?“; „Do akej 
miery máte schopnost' vytrvat'?". Vyššie skóre dosiahnuté v UPCC poukazuje na vyššiu mieru vnímaných proaktívnych zvládacích kompetencií. V zahraničných štúdiách UPPC vykazuje dobrú vnútornú konzistenciu $(\alpha=0,83-0,95)$, test-retest realiabilitu $(r=0,45-0,82)$ a senzitivitu voči zmenám po edukatívnych intervenciách u zdravej mladej populácie, u l’udí v neskoršej dospelosti a u l'udí s dvoma typmi cukrovky (Bode, Thoolen, de Ridder, 2008; Tielemans et al., 2014).

\section{3 Štatistické spracovanie dát}

Na skúmanie stanovených ciel’ov sme použili pre výpočet vnútornej konzistencie dotazníka koeficient Cronbachova alpha. V prípade analýzy faktorovej štruktúry sme sa rozhodli použit' exploračnú faktorovú analýzu, v prípade originálneho jednofaktorového modelu bez rotácie a v prípade nami navrhovaného štvorfaktorového modelu EFA s rotáciou Varimax. Pri spracovaní dát sme použili software IBM SPPS Statistics 25 a IBM SPSS Amos 21.

\section{VÝSLEDKY}

\subsection{Vnútorná konzistencia škál nástroja UPCC}

Vnútorná konzistencia pôvodnej verzie dotazníka administrovanej pacientom po CMP škály nástroja UPCC vykazovala dobré hodnoty vo svojom jednofaktorovom originálnom riešení $\alpha=$ 0,79 . V prípade nami navrhovaného 4-faktorového riešenia, ktoré uvedieme v podkapitole Exploračná faktorová analýza, vzhl’adom aj na menší počet položiek v jednotlivých faktoroch, vnútorná konzistencia klesla. Počet položiek totiž ovplyvňuje odhad reliability (Urbánek, Denglerová, Širůček, 2011). Hodnoty zistenej vnútornej konzistencie uvádzame v Tabul'ke 1.

Tab. 1 Cronbachova alpha škál štvorfaktorového modelu nástroja UPCC, pri $\mathrm{n}=77$

\begin{tabular}{|l|c|c|c|c|}
\hline Vnútorná konzistencia & F1 & F2 & F3 & F4 \\
\cline { 2 - 5 } UPCC (4-faktory) & 0,686 & 0,679 & 0,670 & 0,634 \\
\hline
\end{tabular}

Legenda: F - faktor

\subsection{Exploračná faktorová analýza nástroja UPCC}

Vhodnost' použitia faktorovej analýzy potvrdila štatistická významnost' Bartlettovho testu sféricity ( $\mathrm{p}<0,001)$ a Kaiserova-Mayerova-Olkinova miera adekvátnosti výberu položiek (KMO =0,639). Môžeme teda usúdit', že normálne a parciálne korelácie položiek sú významné a použitie faktorovej analýzy má zmysel (Field, 2005; Kaiser, 1974; Stevens, 2002).

V prípade originálneho jednofaktorového riešenia sme volili exploračnú faktorovú analýzu bez rotácie. Kvôli niektorým problematickým položkám sme sa rozhodli navrhnút' viacfaktorový model dotazníka. Ako najviac komplexný sa preukázal 4-faktorový model nástroja, ktorého riešenie uvádzame v nasledujúcich tabul'kách. Na základe zmieneného modelu sme identifikovali štyri oblasti proaktívneho zvládania, ktoré popíšeme v časti diskusie. V prípade štvorfaktorového riešenia sme zvolili rotáciu Varimax, ked'že faktory, ktoré sme explorovali vzájomne nekorelovali, v niektorých prípadoch bola ich vzájomná tesnost' stredne silná. 
Tab.2 Faktorová štruktúra pôvodnéhojednofaktorového riešenia dotazníka UPCC (bez rotácie), pri $\mathrm{n}=77$

\begin{tabular}{|c|c|c|}
\hline & Položky & Faktor 1 \\
\hline \multirow{23}{*}{ UPCC } & 1 & ,398 \\
\hline & 2 & ,531 \\
\hline & 3 & ,468 \\
\hline & 4 &, 320 \\
\hline & 5 & ,464 \\
\hline & 6 & ,394 \\
\hline & 7 & ,419 \\
\hline & 8 & ,537 \\
\hline & 9 & ,364 \\
\hline & 10 & ,229 \\
\hline & 11 &,- 076 \\
\hline & 12 & ,577 \\
\hline & 13 & ,656 \\
\hline & 14 &, 541 \\
\hline & 15 &, 446 \\
\hline & 16 & 319 \\
\hline & 17 & ,719 \\
\hline & 18 &, 534 \\
\hline & 19 &, 547 \\
\hline & 20 &, 573 \\
\hline & 21 & ,201 \\
\hline & Eigenvalue & 4,613 \\
\hline & $\%$ variancie & 21,965 \\
\hline
\end{tabular}

Legenda: UPCC - Utrecht Proactive Coping Competence scale

V prípade originálneho jednofaktorového riešenia dotazníka sú faktorové náboje položiek stredne silné až silné, s výnimkou troch položiek 10,11 a 21, kde je absolútna hodnota sýtenia faktorom < 0,30. Ostatné faktorové sýtenia sú stredne silné až silné, čo preukazuje akceptovatel'nost' jednofaktorového riešenia dotazníka UPCC. Faktor spolu vysvetl'uje 21,97 \% rozptylu (Tab. 2).

Na základe nedostatočného faktorového sýtenia troch položiek dotazníka a malého percenta vysvetlenej variancie sme sa rozhodli zrealizovat' viacfaktorové riešenia (2,3 aj 4 - faktorové). Štvorfaktorové riešenie, ktoré uvádzame v nasledovnej tabul'ke sa javilo ako najlepšie a komplexné. 
Tab. 3 Faktorová štruktúra navrhnutého štvorfaktorového riešenia dotazníka UPCC(rotácia Varimax), pri n = 77 (uvádzame faktorové sýtenie položiek $>|0,30|$ )

\begin{tabular}{|c|c|c|c|c|}
\hline \multirow{2}{*}{ Položky } & \multicolumn{4}{|c|}{ Faktory } \\
\hline & 1 & 2 & 3 & 4 \\
\hline 1 & & ,578 & & \\
\hline 2 & & ,662 & & \\
\hline 8 & & ,644 & & \\
\hline 9 & & ,721 & & \\
\hline 10 & & ,389 & & \\
\hline 14 & & ,472 & ,344 & \\
\hline 3 & ,301 & & & \\
\hline 6 & ,434 & & & \\
\hline 17 &, 590 & ,407 & & \\
\hline 18 & ,608 & & & \\
\hline 19 & ,763 & & & \\
\hline 20 & ,680 & & & \\
\hline 21 & ,445 & ,319 &,- 419 &,- 406 \\
\hline 5 & & & ,418 & \\
\hline 7 & & & ,531 & \\
\hline 12 & & &, 792 & \\
\hline 13 & ,314 & & 694 & \\
\hline 15 & ,385 & & ,448 &,- 445 \\
\hline 4 & & & & ,716 \\
\hline 11 & & & & ,732 \\
\hline 16 & ,305 & & & 648 \\
\hline Eigen. & 4,613 & 2,139 & 1,678 & 1,550 \\
\hline$\%$ var. & 21,96 & 10,18 & 7,992 & 7,382 \\
\hline
\end{tabular}

Legenda: Eigen.- Eigenvalues, \% var. - \% variancie

Každá z položiek v danom modeli je sýtená príslušným zo štyroch faktorov, aj ked' zjavné sú tiež sýtenia inými faktormi, avšak prevažne v slabších, prípadne záporných hodnotách. Vysvetlené percento variancie modelu vzrástlo a štyri explorované faktory spolu vysvetl'ujú 47,53\% rozptylu. Vzhl'adom na logickú príslušnost' jednotlivých položiek v štyroch faktoroch sme si zvolili pracovné názvy pre explorované faktory, čo nám umožňuje exploračno-verifikačný charakter predkladanej štúdie (Tab. 3).

\section{DISKUSIA}

Hlavným ciel’om prezentovanej štúdie bolo overit' reliabilitu a faktorovú štruktúru slovenského prekladu Utrecht Proactive Competence Coping Scale na súbore pacientov po prekonaní CMP. Podl'a pôvodných autorov dotazníka (Bode, Thoolen, de Ridder, 2008) proaktívne zvládacie stratégie pacientov po CMP tvoria jeden faktor opisujúci mieru proaktívneho zvládania pacientov po CMP. 


\subsection{Vnútorná konzistencia nástroja UPCC}

$\mathrm{V}$ rámci overovania reliability sme sa zamerali na zistenie úrovne vnútornej konzistencie dotazníka, prostredníctvom vypočítania Cronbachovho koeficientu alfa. Pre pôvodný jednofaktorový model dotazníka sme zistili hodnotu $\alpha=0,79$. Za hraničnú hodnotu koeficientu alfa, ktorá určuje akceptovatel'nost' dotazníka z hl'adiska reliability, sa všeobecne považuje hladina 0,7 (Halama, 2005). Výsledky koeficientu vnútornej konzistencie preto poukazujú na dostatočnú vnútornú konzistenciu jednofaktorového modelu dotazníka. Vzhl'adom na nie celkom ideálne jednofaktorové riešenie a vzhl'adom na faktorové sýtenia jednotlivých položiek dotazníka $(10,11$ a 21; Tab. 2), sme navrhli štvorfaktorový model dotazníka, v rámci ktorého vnútorná konzistencia jednotlivých nami navrhovaných faktorov klesla (Tab.1) aj vzhl'adom na menší počet položiek v jednotlivých faktoroch. Počet položiek totiž ovplyvňuje odhad reliability (Urbánek, Denglerová, Širůček, 2011). V prípade, že sa jedná o osobnostný dotazník je podl'a Aikin (In Halama, 2005; Traub, 1994) prijatel’ná úroveň Cronbachovej alfy .60 - .70.

\subsection{Faktorová štruktúra dotazníka UPCC}

Vzhl’adom na spomínané nedostatky vo faktorovej štruktúre jednofaktorového modelu dotazníka, ktorého faktor spolu vysvetl'uje 22\% rozptylu sme navrhli štvorfaktorové riešenie dotazníka, v rámci ktorého sa upravili faktorové sýtenia daných položiek a faktory spolu vysvetl'ujú väčšie percento rozptylu - 48\%. V rámci zmyslu daných položiek má explorovanie jednotlivých faktorov zmysel pre detailnejšiu analýzu štruktúry proaktívneho zvládania pacientov po CMP. Nami navrhovaný model v stručnosti popíšeme.

Exploračná faktorová analýza identifikovala 4 faktory schopností proaktívneho zvládania. Prvý faktor sme nazvali Analýza situácie. Položky tohto faktoru sa sústred'ujú na to ako respondent hodnotí svoje limity, na schopnost' rozoznat' prekážky, ktoré mu komplikujú riešenie, schopnost' poučit' sa z neúspechu a nájst' pozitívne aspekty stresovanej situácie či riešenia. Tento faktor je sýtený položkami - 3., 6., 17., 18., 19., 20., 21. Príklad položky: 18. Do akej miery máte nasledujúce zručnosti - Zvažovat' pozitívnu stránku neúspechu? Faktor Analýza situácie vypovedá o kompetencii probanda analyzovat' svoju aktuálnu situáciu v ktorej sa nachádza, zhodnotenie riešenia situácie a vyvodenie pozitívnych konzekvencií. Tento faktor zhl'adiska obsahu do vel'kej miery korešponduje s adaptívnymi zvládacími stratégiami podl'a BRIEF COPE - Copingovým stratégiám zameraným na problém, konkrétne ide o subdimenzie: pozitívne prerámcovanie (Carver, Scheier, Weintraub, 1989; Hegarty, D., Buchanan, B. 2021).

Druhý faktor sme pomenovali - Predikcia riešenia problému. Položky ktoré tvoria tento faktor sa zameriavajú na predikovanie potenciálneho vývinu situácie a zároveň schopnosti zhodnotit' svoje kroky do budúcnosti. Tento faktor je tvorený položkami. 1., 2., 8., 9., 10., 14. Príklad položky: 8. Do akej miery máte nasledujúce zručnosti - Jasne určit' veci, ktoré chcem dosiahnut'? Faktor vypovedá o kompetencii probanda predikovat' vývoj situácie a na jeho základe vytvárat’ plány do budúcnosti. Tento faktor z hl'adiska obsahu zodpovedá adaptívnym zvládacím stratégiám podl'a BRIEF COPE - Copingovým stratégiám zameraným na problém, konkrétne subdimenzii plánovanie (Carver, Scheier, Weintraub, 1989).

Tretí faktor sme pomenovali Zdroje a riešenia problému. Položky ktoré sýtia tento faktor a zaoberajú sa schopnost'ou probanda nachádzat' osobné zdroje aj zdroje prostredia. Obsahujú schopnosti explorovat' situáciu a definovat' dostupné riešenia problému a vytrvalost' v ich hl'adaní. Faktor je tvorený položkami: 5., 7., 12., 13., 15. Príklad položky: 12. Do akej miery máte nasledujúce zručnosti - Nachádzat' riešenia? Faktor vypovedá o kompetencii a vytrvalosti klienta nachádzat' zdroje a možnosti riešenia problému. Tento faktor $\mathrm{z}$ hl'adiska obsahu do vel'kej miery korešponduje s adaptívnymi zvládacími stratégiámi podl'a BRIEF COPE - Copingovými stratégiámi zameranými na problém, subdimenzia - aktívny coping (Carver, Scheier, Weintraub, 1989). 
Štvrtý faktor sme pomenovali Sociálna opora. Položky faktora sa zaoberajú tým, nakol'ko je pacient ochotný využívat' sociálne zdroje vo svojom okolí, nakol'ko je otvorený skúsenostiam a názorom okolia a možnostiam požiadat' o pomoc v náročných životných situáciách. Faktor je tvorený položkami 4., 11., a 16. Príklad položky: 16. Do akej miery máte nasledujúce zručnosti Hl'adat' podporu ked' sú veci t'ažké? Faktor vypovedá o kompetencii využit' sociálne zdroje a oporu, korešponduje s adaptívnymi zvládacími stratégiámi podl'a BRIEF COPE, konkrétne subdimenziami - emocionálna opora a aj využívanie informačnej podpory (Carver, Scheier, Weintraub, 1989).

\section{ZÁVER}

Skúmané psychometrické vlastnosti nástroja UPCC hodnotíme ako akceptovatel'né. Zistená vnútorná konzistencia podporila reliabilitu nástroja. V štúdii bola preskúmaná pôvodná jednofaktorová aj navrhovaná štvorfaktorová štruktúra dotazníka. Limitom predkladanej štúdie je v prípade sledovanej faktorovej štruktúry dotazníka analýza na menšom počte sledovaných respondentov. Do budúcich skúmaní by sme odporúčali preto pracovat' s väčším počtom respondentov, v rámci analýz by bolo potom vhodné použit' konfirmačnú faktorovú analýzu na overenie pôvodného unidimenzionálneho, ale aj nami navrhovaného štvorfaktorového modelu dotazníka UPCC. Kspol’ahlivému používaniu nástroja UPCC v slovenských podmienkach odporúčame pokračovat' v overovaní psychometrických vlastností nástroja a zhodnotit' napríklad aj jeho konvergentnú, diskriminačnú a kriteriálnu validitu.

\section{LITERATÚRA}

Aben, I., Verhey, F., Honig, A., Lodder, J., Lousberg, R., \& Maes, M. (2001). Research into the specificity of depression after stroke: a review on an unresolved issue. Progress in NeuroPsychopharmacology and Biological Psychiatry, 25(4), 671-689.

Bode, C., Thoolen, B., \& de Ridder, D. (2008). Measuring proactive coping. Psychometric characteristics of the Utrecht Proactive Coping Competence scale (UPCC). Psychologie \& Gezondheid, 36(2), 81-91.

Carod-Artal, F. J., \& Egido, J. A. (2009). Quality of life after stroke: the importance of a good recovery. Cerebrovascular diseases, 27 (Suppl. 1), 204-214.

Carver, C. S., Scheier, M. F., \& Weintraub, J. K. (1989). Assessing coping strategies: A theoretically based approach. Journal of Personality and Social Psychology, 56(2), 267-283.

Darlington, A. S. E., Dippel, D. W., Ribbers, G. M., van Balen, R., Passchier, J., \& Busschbach, J. J. (2009). A prospective study on coping strategies and quality of life in patients after stroke, assessing prognostic relationships and estimates of cost-effectiveness. Journal of Rehabilitation Medicine, 41(4), 237-241.

Field, A. P. (2005). Discovering Statistics using SPSS. London: Sage.

Greenglass, E. (2002). Proactive coping. In E. Frydenberg (Ed.), Beyond coping: Meeting goals, vision, and challenges (pp. 37-62). London : Oxford university Press.

Greenglass, E. R., \& Fiksenbaum, L. (2009). Proactive coping, positive affect, and well-being: Testing for mediation using path analysis. European Psychologist, 14(1), 29-39.

Halama, P. (2005). Princípy psychologickej diagnostiky. Trnava, Trnavská Univerzita v Trnave. 
Haley, W. E., Roth, D. L., Kissela, B., Perkins, M., \& Howard, G. (2011). Quality of life after stroke: a prospective longitudinal study. Quality of Life Research, 20(6), 799-806.

Hegarty, D., \& Buchanan, B. (2021). The Value of NovoPsych Data - New Norms for the Brief-COPE. NovoPsych. https://novopsych.com.au/news/the-value-of-novopsych-data-new-norms-for-thebrief-cope

Kaiser, H. (1974). An index of factorial simplicit. Psychometrika, 39 (1), 31-36.

Kauhanen, M. L., Korpelainen, J. T., Hiltunen, P., Nieminen, P., Sotaniemi, K. A., \& Myllylä, V. V. (2000). Domains and determinants of quality of life after stroke caused by brain infarction. Archives of physical medicine and rehabilitation, 81(12), 1541-1546.

Lazarus, R.S., Folkman S. (1984). Stress, appraisal and coping. New York: Springer Publishing Co.

Mackay, J., Mensah, G. A., \& Greenlund, K. (2004). The atlas of heart disease and stroke. Geneva: WHO

Sarti, C., Stegmayr, B., Tolonen, H., Mähönen, M., Tuomilehto, J., \& Asplund, K. (2003). Are changes in mortality from stroke caused by changes in stroke event rates or case fatality? Results from the WHO MONICA Project. Stroke, 34(8), 1833-1840.

Stevens, J. (2002). Applied Multivariate Statistics for the Social Sciences (4th Edition). Mahwah, NJ: Lawrence Erlbaum Associates.

Tielemans, N. S., Visser-Meily, J. M., Schepers, V. P., Post, M. W., \& van Heugten, C. M. (2014). Proactive coping poststroke: psychometric properties of the Utrecht Proactive Coping Competence Scale. Archives of physical medicine and rehabilitation, 95(4), 670-675.

Traub, R. E. (1994). Reliability for the social sciences: Theory and applications. London: Sage.

United Nations (2009). World Population Ageing 2009. New York: United Nations, Department of Economic and Social Affairs Population Division.

Urbánek, T., Denglerová, D., \& Širůček, J. (2011). Psychometrika: měření v psychologii. Portál.

\section{PSYCHOMETRIC PROPERTIES OF SLOVAK VERSION OF UTRECHT PROACTIVE COMPETENCE COPING SCALE}

Abstract: The aim of the present study is to analyze the reliability and factor structure of the Slovak translation of the Utrecht Proactive Competence Coping Scale (Bode, Thoolen, de Ridder, 2008), which is intended for patients in convalescence after a stroke. The research group consisted of 77 patients - $50(64.9 \%)$ men and 27 women $(35.1 \%)$ who overcame stroke. To verify the factor structure of the questionnaire, we used the method of exploratory factor analysis, where in addition to the structure of the original one-factor model, we also design a four-factor model. The results indicate a more suitable four-factor structure of the UPCC questionnaire, good values of the internal consistency of the questionnaire in its one-factor and four-factor structure. The limitation of the study is a smaller number of respondents. We consider the identification of four possible factors of the questionnaire, which encourage a more detailed insight into the proactive management mechanisms of patients after stroke, to be a benefit of the analyzes.

Key words: proactive coping, stroke, psychometric properties.

\section{Grantová podpora:}

Príspevok vznikol ako súčast' riešenia grantového projektu VEGA 1/0418/19 Zvládanie zát'aže v procese rekonvalescencie po cievnej mozgovej príhode. 